\title{
Technology Transfers and Knowledge Management in Developing Economies: Case Study of an Indonesian Manufacturer
}

\author{
Wahyudi Wibowo*
}

\begin{abstract}
International technology transfers are crucial for developing economies since they may operate as one of the key drivers in the economies' development path. Previous studies have acknowleged some channels of technology transfers for developing economies. Nevertheless, the precise mechanisms of how the technology transfers would occur and take effect in each of the recipient economies and their domestic companies are still to be explored. Furthermore, understanding domestic companies knowledge management is important since it would determine the absorptive capacity of the company toward advanced foreign technologies. This study uses a case of technologically intermediate-level Indonesian manufacturer to show evidence of international technology transfers and their impacts on the development of indigenous technological capabilities of the domestic company, as well as to examine the company's knowledge management.

This study confirmed some benefits of international technology transfers for the domestic company, especially through the major mechanisms of technical license assistances, capital goods imports, turnkey projects, technical consultancies, backward-vertical flows of foreign direct investment, and participation in overseas markets. However, the impacts toward the domestic company's technological capabilities were generally at intermediate level. This implies that the domestic company needs to spend more investments on in-house $R \& D$ activities and to improve its knowledge management systems.
\end{abstract}

Keywords: technology transfers, technological capabilities, reseach and development, knowledge management, developing economies.

\footnotetext{
* Dr. Wahyudi Wibowo, Business School, University of Pelita Harapan Surabaya, corresponding address: University of Pelita Harapan Surabaya, Tokyo Tower, 7th Fl., Cito Superblock, Jl. A. Yani no. 288, Surabaya (60234), Indonesia, email: wahyudi.wibowo@uphsurabaya.ac.id or yudiwbw@yahoo.com.
} 


\section{Introduction}

One of the most important factors which explain the remarkable economic development in many developing economies during the past four decades is the existence of international technology transfers. The involvement of international technology transfers has been acknowleged as bringing positive roles on the economic developments of some East Asian and Latin American developing economies since 1970s. This includes their roles in encouraging the accumulation of indigenous technological capabilities (hereafter referred to as TC) in the manufacturing sectors (Tolentino, 1993).

However, the roles of international technology transfers have apparantly appeared to vary in each of the developing economies. Some successful economies have made a technologically closer catch-up with the developed economies, for instance, in the cases of the newly industrialized economies of Hongkong, Taiwan, South Korea, Singapore, and Brazil. But many others performed moderately or poorly in their technological developments. Furthermore, while technology transfers may occur in an economy, eventually the true challenge is how the domestic companies or workers in the host economy could absorb and master the transferred technologies and how not to let the technologies remain isolated in the foreign companies or expatriate workers (Thee, 2005).

In this regard, there are two clear observations. First, many developing economies have benefited from international technology transfers. The majority of the world's research and development (hereafter R\&D) activities is in hands of few industrially developed economies, yet productivity gains are widespread across developing economies. Second, international technology transfers are not frictionless and their impacts on the productivity of the recipient economies are neither automatic nor evenly distributed (Xu and Chiang, 2005; Unesco, 2010). The latter implies that technology transfers might be stipulated under certain conditions, in which absorptive capacities of the economies such as human capital, technological level, and other institutional factors play important roles (Thee, 2005). This raises a question on the precise mechanisms of the technology transfers and how they give effect to the recipient economies.

The main objective of this paper is to give a case in point on the impacts of foreign technology transfers on the TC level of domestic company which operated in developing economy. Furthermore, it aims to study how the company manages its absorptive capacities toward the foreign technologies. This is particularly discussed in relation to the knowledge management of the domestic company.

The evidences revealed in this study may enrich the previous findings and contribute to deepening the analysis on the studies of international technology 
transfers in developing economies. Moreover, the focus on the impacted domestic company will give more understanding on the developments of indigenous TC in a developing economy. This offers a distinctive feature compared to the previous studies in this field which often did not exclude the case of foreign companies in their examinations. The results also suggest several important managerial implications regarding the issue of knowledge management for domestic companies in developing economies.

\section{Literature review}

This section provides a survey on the theories of international technology transfers and knowledge management in developing economies, including some of the related empirical works. To begin with, these are some definitions of the key terms used throughout this paper.

Technology is broadly defined as the production methods, managerial practices, codified know-how and other tacit knowledge by which a company transforms capital, labor, and materials into a product (Blalock and Gertler, 2005). Another useful definition is to describe technology as the knowledge and machinery needed to run a company, which include both hardware (machineries and other capital equipment) and software (blueprints and manuals) of the whole company (Thee, 2001; Chee, 1981).

International technology transfers are acknowleged as the cross-border transfers of embodied technology in imported machineries and other capital equipments, as well as other diffusions of skills and technical knowhow. International technology transfers can be divided into two categories, based on their modes of transfer. Technology transfers that come from direct economic activities are categorized in the formal mode, while ones that come from indirect economic activities are categorized in the informal mode. The formal mode of technology transfers is made possible because technology as a form of knowledge has an important property of economic commodity. Technology is a nonrival good that can be disseminated and used simultaneously in many economic entities (Grossman and Helpman, 1992).

When the technology transfers take place indirectly, it is usually called technology spillovers. Technology spillovers apply when: (1) companies can acquire knowledge created by others without paying for that knowledge in a market transaction, and (2) the creators or the current owners of the knowledge have no effective recourse, under prevailing laws, if other companies make unauthorized use of the acquired knowledge (Grossman and Helpman, 1992). 


\section{Technology transfers in developing economies}

International technology transfers have been intensively studied in the literatures. In this regard, there are some channels of technology transfers available for developing economies. First, the formal mode of transfer which consists of FDI, technical licensing agreements (hereafter TLA), imports of capital goods, foreign education and training, turnkey projects, and technical consultancy. Second, the informal mode of transfer which may take place via participation in overseas markets and reverse engineering (Thee, 2005; 2001).

The next parts of this section will discuss the importance of each of the channels of technology transfers. TLA, imports of capital goods, foreign education and training, turnkey projects, and technical consultancy are often considered as important channels of technology transfers where domestic companies in developing economies can utilize them through direct transactional ways. They often involve the transfers of older technologies from advanced industrialized economies that do not offer the recipient a longterm competitive advantage in the global market. However, for companies in developing economies these channels provide affordable ways to increase their level of technological development. In addition, imports of intermediate inputs are also regarded as formal mode of technology transfers (Grossman and Helpman, 1992; Markusen, 1989). Companies which import intermediate inputs from advanced economies may also enjoy productivity gains.

With regard to FDI, it is important to note on the aforementioned classification that technology transfer through FDI is often considered in the literatures as a formal mode of transfer. That is to see it as technology transfer from the parent multinational corporation (hereafter $\mathrm{MNC}$ ) to its own foreign affiliate. However, technology transfer from FDI to the non-affiliated domestic companies actually occurs informally. Hence, as much of the concern of this study, technology transfers through FDI will be regarded as an informal way of transfer. Another way to explain it is to see that MNCs have to be good at preserving their specific advantages from domestic competitors. Therefore technology transfers through FDI may only take place indirectly in terms of technology spillovers (Dunning, 1993).

Moreover, technology transfers from FDI toward domestic companies can be distinguished into two major channels, namely horizontal- and vertical-flows. In the horizontal-flow spillovers, MNCs may provide positive technological spillovers to domestic competitors through several mechanisms. First, domestic companies can learn simply by observing and imitating the MNCs' product innovations and business practices (demonstration effects). Second, increased competition from foreign owned companies may induce 
domestic companies to reduce their inefficiencies (competition effects). Third, employees may leave MNCs to create or join domestic companies.

The vertical-flows of spillovers may occur through the supply chain relationships in either backward linkage, i.e. from MNCs to domestic suppliers, or forward linkage, i.e. from MNCs to domestic buyers. In this regard, there are two arguments which suggest that the spillovers may more likely to take place through backward linkage mechanism. First, while MNCs seek to minimize technology leakage to competitors, they have incentive to improve the productivity of their domestic suppliers, especially in the areas of training, quality control, and inventory management. Second, while the technology gap between foreign and domestic producer may limit withinsector full technology transfer, MNCs likely procure inputs requiring less sophisticated production technology for which the gap is usually narrower (Blalock and Gertler, 2005).

Participation in overseas markets can also be a channel of technology transfers when domestic companies do learning by exporting. Interactions with foreign customers and competitors provide important information on new products and technologies that allow domestic companies to efficiently produce and improve their product qualities. Exporting creates opportunities of direct contacts with various levels of demand and preferences in foreign markets, and doing export to technologically more sophisticated markets presumably generates higher spillovers (Thee, 2005). Furthermore, foreign customers from advance economies may offer technical assistance to exporting companies to adapt their products and technologies to the requirements of international markets. This is particularly evidenced in the cases of developing economies' outsourcing manufacturers (Pack and Saggi, 2001).

Reverse engineering is another important channel of technology spillovers in developing economies, especially regarding their limited R\&D spending (Unesco, 2010). Reverse engineering is a process of discovering the technological principles of a machine through the analysis of its structure, function and operation. This process in developing economies often involves taking apart a machine from technologically advanced economies and analyzing its functions in detail for the purpose of maintenance work or sometimes in order to make a new machine that does the same function but with minor modifications.

Indigenous technological capabilities and knowledge management International technology transfers may increase the level of indigenous TC for companies in developing economies. TC means the skills, technical, managerial and institutional capabilities that enable manufacturing enterprises to utilize 
capital equipment and technical information efficiently (Thee, 2001). TC can be differentiated into two types, i.e. know-how and know-why. Know-how is about practical knowledge of certain production processes, maintenance, or application of a product and of its sales. Know-how is acknowledged in the form of formula, designs, procedures and methods, together with the accumulated skills and experience which are usually known as tacit knowledge. In contrast, know-why is about the scientific knowledge which represent the understanding of the principles of nature and usually codified.

At the early stage of TC development, transfers of one type of TC named know-how are needed. However, in order to let companies from developing economies catch-up with the same level of development of the companies from developed economies, another type of TC named know-why is required. Therefore, in order to further develop TC at a more advanced level of development, purposeful investments in searching for new technological innovations through R\&D are essentially needed (Tolentino, 1993). In this respect, technology-importing economies have the challenge to maximize the transfers of the most relevant technologies. This is not simply about importing advanced technology machineries or acquisitions of the formula of sophisticated materials, but more importantly, its relation to the development of TC. Further development of TC, particularly a forward from know-how to know-why through investments in R\&D, is crucial for the competitive advantage of manufacturing companies in developing economies (Thee, 2005).

Furthermore, the level of TC at the company level can be classified as follows: (1) Production or operational capability, which refers to the knowledge and skills required for the efficient operation and control of production process and the machinery in the plant, including maintenance and repairs; (2) Investment or acquisitive capability, which refers to the knowledge and skills required to search, assess, negotiate, and procure the relevant technologies. Moreover, it includes the capability to install and start-up the new production facilities; (3) Adaptive or minor change capability, which refers to the knowledge and skills required to digest the transferred technologies and to carry out minor modifications or improvements in the existing process or product technologies in response to changing circumstances and/or to raise productivity; (4) Innovative or major change capability, which refers to the capability required to carry out significant in-house R\&D in order to make radical process or product modifications and develop new products or processes (Thee, 2005; Kim, 1997).

The development of TC, with respect to the influence of international technology transfers, will need a proper organizational learning. Organizational learning is considered as the company's absorptive capacity toward foreign 
technologies (Dutrenit, 2000; Cohen and Levinthal, 1990). Organizational learning here is understood as the process through which companies create knowledge and acquire TC.

The process of organizational learning is created via a rather complex mechanism. The process basically takes place at two levels: individual and organizational. Learning process at the organizational level is not an automatic process of the accumulation of individual knowledge and, vice versa, what an individual learns depends on what is already learnt by the other members of organization at the organizational level (Dutrenit, 2000). Learning process usually first occurs at individual level and afterward needs to be intentionally converted into organizational level, in order to spread the individual knowledge to the other members in the organization. This process is typically made possible by effective coordination of learning and knowledge integration.

The more complex innovational activities faced by an organization, the higher the need to integrate knowledge across technological and organizational boundaries. Companies need to integrate knowledge all the time at different organizational levels in a way that allows the internal structure and processes to: (1) identify and develop specialized knowledge within technological fields, business functions and production divisions, (2) exploit this knowledge through integration across technological fields, business functions and production divisions (Dutrenit, 2000; Pavitt, 1991).

Therefore, knowledge management is fundamental for a company to build its TC. Knowledge management is a set of purposeful efforts in an organization to coordinate learning processes and to integrate knowledge across functions and at all organizational levels. This is a departure from the traditional method of knowledge specialization. The objective is to get the strategic use of the acquired knowledge at the organizational level. In this sense, the knowledge management of a company in developing economies is suggested to proceed at different stages (Dutrenit, 2000). At the initial stage, a company has to build and accumulate a minimum essential knowledge base of TC to engage in innovative activities. This initial stage of TC includes the capabilities to reduce costs, improve product's quality and upgrade the equipment to achieve parity with the leading competitors. This stage deals with the accumulation of some basic to intermediate-innovative level of TC.

Afterward, the company needs to move into the transition stage to pay adequate attention to two particular issues: (i) the organizational and managerial aspects of TC building throughout the company, and (ii) as the company approaches the internationally technological frontiers and seeks to build more complex and integrated knowledge bases, an advanced stage of technological accumulation is needed to make the strategic use of that 
knowledge. At this transition stage, the emergence of embryonic strategic capabilities in some technical-functions or knowledge fields are expected. Therefore this stage deals with the accumulation of some intermediate- and advanced-innovative levels of TC.

Then, at the final stage, the company is expected to build its strategic capabilities which distinguished the company competitively from its competitors. At this stage, the company should also continually maintain and renew its strategic capabilities. This stage especially deals with the accumulation of advanced-innovative TC in all of the technical functions.

\section{Major channels of technology transfers in Indonesian manufacturing sector}

Indonesia has long ranging aims on industrialization. After some periods of isolation, since 1967 the economy has gradually opened for foreign investment in order to boost productions and to speed up its technological development. Since the mid of 1980s the economy has also adopted greater openness to trade, including imports of machineries and intermediate goods, in order to enhance its exports of manufactures. In this regard, like many other developing economies, Indonesia is categorized as a net importer of advanced technologies. However, its level of technological development, when compared to the East Asian's newly industrialized economies, is relatively still under-developed (Thee, 2005); suggesting its low level of absorptive capacities.

Comprehensive assessments by Thee $(2005,2001)$ toward international technology transfers across industries in Indonesia, which include the textile, garment and electronics industries of the late 1990s, indicated that there had been only four major channels of technology transfers in Indonesian manufacturing sectors. Those are FDI, TLA, capital goods imports, and participation in overseas markets. Morever, the studies concluded that the technology transfers typically took place successfully only at the production or operational level of TC. There are only a few of them performed at the investment or acquisitive level. Note that the study observed the cases of international technology transfers in foreign-owned companies in Indonesia. Most of them were under large controls of foreign managers and technical experts. Hence local workers did not learn much from the imported technologies.

Lipsey and Sjoholm (2005) conducted a survey of empirical studies on technology spillovers in Indonesian manufacturing industry. The study found statistically significant effects of intra-industry technology spillovers, with only little effects that came from inter-industry mechanism. It means that backward-vertical flows of FDI spillovers, through supply chain transactions 
between multinationals and domestic companies, had been an important conduit for technology transfers, for example, in the cases where some of the American, Japanese and German MNCs confered technical and production advice to their qualified domestic suppliers (Blalock and Gertler, 2005). Some other multinationals even provided useful guidance on how to access international loans, expand the production capacity and how to design new products.

Another study by Jacob and Szirmai (2007) found that the involvement of Indonesian manufacturers in international trade, both via imports and exports, was also regarded as an important channel of technology spillovers. In this sense, capital goods imports from advanced economies were positively associated with technological learning. However, the contribution from exports was found to be less important than imports.

\section{Research method}

In order to pursue its objective, this study reviews the case of technology transfers in TRST, an intermediate-level technology Indonesian manufacturer. The company's data for the period of 1979-2008 was gathered through various ways, i.e.: literature survey on the company's official documents, indepth interviews with some of the executives and plant managers, and several direct observations. The observations were conducted via plant visits which were combined with seat-in attendances on some of the daily operational meetings and employee training events during the periods of 2006-2008. The status of the company as a public listed entity gives advantage for the disclosure of the data.

The utilization of company-level data allows this study to focus on the detail mechanisms of the technology transfers throughout the company, as well as on the many aspects of the company's knowledge management systems. Hence this study is expected to give more explanation on the transfer mechanisms of foreign technologies. Also, this may help researchers in this field to further examine their econometric model and statistical analysis. This is in relation with the nature of a case study analysis which gives advantage of being rich in details. However, a caveat for this approach is that the findings might be merely indicative than explanatory, thus the findings may not be generalized.

\section{TRST: a forward move from domestic to global player}

TRST is a flexible packaging manufacturer which was established in November 1979. The company started its initial commercial production with the installed capacity of 4,500 MT per annum in 1986. Currently, its total production 
capacity is 65,000 MT Biaxially Oriented Polypropylene (BOPP) per annum and 32,000 MT Biaxially Oriented Polyester (BOPET) per annum, making the company the largest flexible packaging film manufacturer in Indonesia. The development of the company's production capacities is presented in Table 1.

Table 1. Production capacities of TRST, 1986-2007.

\begin{tabular}{lcccccccc}
\hline & 1986 & 1989 & 1993 & 1995 & 1996 & $\mathbf{2 0 0 3}$ & $\mathbf{2 0 0 5}$ & $\mathbf{2 0 0 7 *}$ \\
\hline BOPP & 4,500 & 12,000 & 24,000 & 24,000 & 40,000 & 50,000 & 50,000 & 65,000 \\
BOPET & - & - & - & 12,000 & 12,000 & 12,000 & 32,000 & 32,000 \\
\hline
\end{tabular}

* The additional capacity in this period was due to the acquisition of a production plant in China.

Source: PT. Trias Sentosa, Tbk., various periods.

TRST envisions to be the most innovative and preferred business partner in flexible packaging industry with a globally recognized brand. The company has been engaged in domestic and global markets. Its clients range from cigarette, snack and food, MSG, printing and lamination, electronic, to adhesive tape industries. Since 2007, the company has commenced its international production in China.

Flexible packaging industry covers the manufacture, supply and conversion of plastic film for retail-food packaging such as snacks and nonfood packaging applications such as cigarettes, personal care, household detergents, pharmaceuticals, and labeling. The products can be made from single-web substrates such as flexible plastics (PE, PP, or PET) or can be coated or laminated with other materials like aluminum foil and paper. Product grades are determined by the combination of clarity, surface gloss, stiffness, heat sealability, and deadfold properties. Therefore product innovation is the key competitive advantage for the industry. Technology wise, according to ISIC classification, flexible packaging products are categorized at intermediatelevel.

While in the global market the degree of competition is high, domestically the flexible packaging industry tends to create oligopoly structure, due to the protections from import tariffs and investment regulations. The Indonesian flexible packaging industry is concentrated into three key domestic players, where each of them has strong affiliates in the domestic tobacco and food industries.

The Indonesian Ministry of Industry in 2007 forecasted flexible packaging industry to continue to develop sustainably, following the growth of food and pharmaceutical industries. However, due to the poor development of chemical industry in the domestic market, the industry is still highly dependent 
on raw material imports, especially on polypropylene and polyethylene resin. Therefore the industry faces critical challenge from the rising cost of oil-based raw materials.

The following parts will present the milestones of the company's TC development, where a large portion of them shows the company's reliance toward various channels of international technology transfers. Afterwards, further parts will discuss the mechanisms in which international technology transfers give effect to the TC development of the company. The last part will present the assesment on the company's knowledge management.

\section{Start-up period (1979-1988)}

The start-up period was indicated by the company's dependence on highskilled foreign engineers and technicians to set up its initial operation. The early times of this period were situated under the condition where knowledge on flexible packaging production was considerably new for the Indonesian economy. This was as well true for the operation of the fully and semi-automated machines used in the plant. Therefore, in this period the installation of major imported machineries and equipments was primarily conducted by foreign engineers and technicians provided by the suppliers. On the other hand, the construction of plant facilities and other minor equipments, such as water and energy utilities, were installed by the local engineers.

When the company was built in 1979, there were not enough local engineers who have the capabilities to set up the plant operation. The local engineers at the middle supervisory level consisted of few inexperienced engineers who graduated from local universities, except only one of them who had been educated and trained abroad. The majority of the workers at the first supervisory and operational level were graduates from high-school or vocational school with many of them having some years of experience in low-level technology manufacturing.

Therefore, in the early periods of production the company relied on few key foreign engineers to lead the set up and operation of the plant. The overall set up and operation of the plant were actually done by foreign engineers through a turnkey project. Those engineers were hired for their experience in the same industry abroad. In this period local engineers and technicians learned much about the new tacit knowledge and technology from their foreign companions. In addition, the local engineers also benefited from the technical assistance and support from foreign technicians of the machine suppliers.

The company started its initial commercial production of BOPP products in 1986, which at that time primarily focused on serving its domestic affiliates. 
Over the next years, in order to enter foreign markets, the company also hired other foreign professionals at the managerial level. They were hired especially due to their knowledge and networks on foreign markets and technical product licensing. As a result, in March 1987 the company began exporting abroad. This practice of hiring expatriates has been continued in the following periods. However, the number of foreign professionals decreased to reach the minimum level while the number of local professionals holding key positions continued to grow.

In summary, in this period TRST was in the early stage of building its minimum essential knowledge base. The focus was to develop some basic TC, especially to acquire and master some technical functions which related to the daily operations of production and maintenance. In regard to the managerial functions, the company was a beginner in learning how to market its products overseas, where most of the knowledge was in hands of its foreign workers.

\section{Rapid growth period (1989-2006)}

This period witnesses a rapid development of TRST's production capacities as well as its TC. TRST had gradually increased its production capacities by the installation of several new plants and product lines, namely metalizing, BOPET, PVdC, and thermal-lamination. The development in the company's TC was indicated by huge investment in new imported machineries, extensive products diversification, a growing number of skilled local workers in the technical and managerial functions, and significant organizational developments.

In this period, the company made huge investments in the utilization of advanced automated machineries imported from Japan and UK, especially for the major machines such as extruder, winder, and cutter; while most of the heavy equipments were imported from Germany. The utilization of cutting-edge technologies from abroad was based on the reasoning that technological development in the production systems is a crucial part for the overall productivity of the company.

Furthermore, it is important to recognize that during this rapid growth period, all of the major projects including the assessment and installation of new production machineries and the building of new plant facilities were successfully conducted by the company's local engineers of the Project Department. This department was basically responsible for the evaluation of new production facility, procurement of the appropriate machineries, and the supervision of the installation and start-up processes of the new production investment.

During this period local engineers showed their technological developments in maintaining and to some extent in making several minor 
modifications to the machineries. This was apparent, considering that some of the imported machineries were second-hand machineries from different manufacturers, therefore they usually needed additional adjustments and modifications. Still, most of the main parts for the machineries repairs were imported. Also, to fulfill the need of high-quality raw materials, which can not be afforded locally, the company depended on foreign supplies mainly from Thailand, Japan, Singapore, and South Korea.

In this growing period, R\&D activities were first introduced. The activities were initially delivered to seek more efficient methods in the production processes, particularly to help reduce the rate of defects. Afterward, the research activities aimed to discover new product innovations in support to the product diversification strategy and to serve the growing demand of specialized products. However, within the limited budget of R\&D, the company was able to conduct only on a small number of research projects which all employed fewer than ten researchers. As a result, there were no product innovations produced. In one of the big R\&D projects, new product development was almost realized. However, the stability of the product's quality was difficult to achieve, so the new product was never brought into production. Therefore to acquire the knowledge of new products formula the company relied a lot on the TLA mechanism, mostly from UK based institution, which was considerably less costly.

To support its growth strategy, TRST initiated some important progress regarding its organizational development. New functions of R\&D, quality assurance, and technical project were taken over by independent departments and embedded into the organizational structure of the company. In 1990 the company entered the Indonesian stocks market. Furthermore, as the opportunities of international sales continued to increase, TRST opened its international representative offices in the USA, Singapore and China, where all of the international sales managers were Indonesians. The company also ctively participated in some international packaging exhibitions.

Since 1995, the Quality Management Systems of TRST has been meeting the ISO 9002 standards and it received certification from the Llyod's Register QualityAssurance Ltd., London. The certification wasa remarkableachievement for the organizational development of the company. This development was initialy delivered in response to the requirements of becoming a preferred supplier for MNCs operated in Indonesia, such as Unilever and British American Tobacco. Likewise, in the early 2000s the company decided to make a huge investment in the implementation of ERP system, named SAP. This was intended to adopt to the world's best manufacturing systems, and opened wider opportunities toward global supply chains. 
Following the technological and organizational developments in the production and managerial fields, in this period human resources development began to attract more attention. For example, the employee profile in 2006 presented a development toward the first period. The total number of employees was 971 people. It was about five times higher compared to the figure in 1988. Importantly almost a quarter of them were university graduates. Training and development activities were also introduced and conducted regularly. Training programs were primarily intended to endorse the dissemination of tacit knowledge in the production and maintenance processes from senior engineers to new engineers and operators. This was important since the company continued to expand the production capacity through the addition of more plants and production lines, and thus consequently needed a lot of new engineers and technicians to handle the daily operations. In contrast to the previous period, where traning programs were all conducted by foreign engineers, many traning programs in this period were delivered by the local senior engineers. Later in the mid of 2000s training programs also included some managerial and behavioral trainings.

Other developments were made under the knowledge management systems of TRST, i.e.: the implementation of daily production meeting and the establishment of Engineering Department. The daily production meeting of all managers and engineers in the production units was an important medium for the company's organizational learning. The daily meeting was conducted through online conference network that enabled personels at all plants to have a meeting at the same time. The daily meeting was quite conducive to generate knowledge sharing across production units, especially on the many issues of daily technical problem solving and quality improvement. Next, the establishment of Engineering Department, which consists of all senior engineers, was also another conduit of organizational learning. This department primarily functioned to facilitate the dissemination of tacit knowledge in the production processes and the regeneration of engineers and technician, as well as to give assistance on non-routine improvement activities in the production units.

During this period, TRST significantly improved its domestic sales performance by acquiring large sales contracts as main supplier for foreign MNCs operated in Indonesia. One of the MNCs operated in personal care industry, while the others operated in tobacco and MSG industries. The contracts demanded a lot of endeavors for the company, especially in fulfilling the standard requirements of quality management (ISO) and logistic management systems. This condition was different from the cases of domestic buyers who did not require high standards on quality management or logistic management systems. 
In the early time of 2000s, the company signed a valuable insourcing contract with a Japan based manufacturer, the accomplishemtn of which required great efforts. Before the agreement ensued, the Japanese manufacturer sent its managers for a plant visit, in order to assess the plant's facilities and particularly its concern for the quality management systems and other product quality standards. The Japanese manufacturer then asked the company to send its product samples. After that, consecutive technical assistance and joint quality control were conducted by the Japanese technicians in the TRST's plant to ensure common language on the products' qualities. Considering the value of the project, the company dedicated one of its production lines to serve the contract.

Another big project which was accomplished in this period was a sales contract with a U.S. based MNC. Before the U.S. MNC appointed TRST as its supplier, some managers had come for a plant visit. Unlike the Japanese manufacturer, the U.S. MNC preferred to conduct a comprehensive and procedural audit toward the plant's production systems and facilities as well as the quality management systems and other requirements such as safety and health standards, security systems, and some of the environmental concerns. The result from the first audit was quite satisfactory. However, it left few requirements to be completed, especially on the implementation of CT-PAT security systems. Responding to the feedback from the prospective buyer, the management of TRST then assigned a special task force to fulfill the requirements. The MNC also asked the company to send its product samples. Within several months afterward, the company had successfully completed the requirements and won the buyer's trust.

The years of 2005 to 2006 were tough for TRST, facing the increase of the raw materials prices following the hike of oil prices. Therefore, the company strived to conduct the production processes more efficiently, especially in terms of material and energy consumption. Since 2005 there had been serious efforts to improve production efficiencies by learning and adopting new production management systems, such as: 5S, Lean Production Management, and Total Productive Maintenance. As informed by one the company's executives, these efforts were in accordance with the guidance from a multinational company, Unilever-Indonesia, where the company once had a chance to conduct a benchmarking study, under the MNC's supplier development program.

In summary, this was a very dynamic period where the company showed some significance progress in its TC development, particularly strengthening its minimum essential knowledge base in the technical functions of production and maintenance. The company also made some valuable progress in some of the managerial functions such as in the quality management, logistic 
management and security systems. All this progress was caused by two determinant factors: large influence of international technology transfers and the building up of organizational learning and knowledge management in TRST.

Additionally, in this period TRST also performed beyond its initial stage of TC development to move to an early phase of transition stage. The early phase of transition stage was indicated by the facts that the company paid some concerns regarding the organizational and managerial aspects of TC development. However, the emergence of embryonic strategic capabilities was not evidenced.

\section{Internationalization period (2007-2008)}

This period was indicated by the fact that while technologically TRST's developments was at its early phase of transition stage, the company's growth was mainly driven by its capital intensive investment abroad. In July 2007, TRST took over the full ownership of a BOPP plant in China with a production capacity of 15,000 MT per annum. The plant was previously owned by a Japanese MNC. The investment cost the company 5.5 million dollars and was expected to create additional sales of 23.5 million dollars. During this period, local engineers were often sent to the plant in China to conduct technical consultations with their partners in China. This overseas investment gave another evidence on the capabilities of the company to asses the feasibility of international investment.

While the company's production methods in many areas had been standardized and therefore required a higher ratio of unskilled labors, in 2008 a new President Director was appointed. He had wide experience in product development and supply chain management in a world-class manufacturing MNC operated in Indonesia. His expertise and international experience were expected to be a value added to TRST, especially to nurture the culture of innovation throughout the company. Following the expansion, the company continued to hire more local professionals preferably thpse with experience in multinational companies and in the areas of supply chain or quality improvement management systems. In this period, traning programs which focus on Lean Production Management and Total Productive Maintenance were also emphasized.

In summary, in this internationalization period TRST focused on improving its TC in some important areas of supply chain and quality improvement management. Some additional capabilities in these areas were due to the contribution of more capable human resources. However, up to this period it was not yet clear what will be the strategic capabilities of TRST, indicating that the company's transition stage was still at its infancy. 


\section{Discussion}

\section{The formal mode of transfers}

In the two subsequent parts, we provide a discussion on each of the modes of technology transfers and how it impacts the the company's level of TC. This part discusses the formal mode of technology transfers which may take place through the mechanisms of TLA, imports of capital goods, foreign education and training, turnkey projects, and technical assistance. The informal mode will be discussed separately in the next part. Table 2 presents the distribution of each of the mechanisms of technology transfers in TRST, while Table 3 summarizes the analysis on the impacts of each of the mechanisms of technology transfers.

Table 2. Technology spillovers matrix in TRST, 1979-2008

\begin{tabular}{|c|c|c|c|}
\hline Modes & $\begin{array}{l}\text { Initial Period } \\
(1979-1988)\end{array}$ & $\begin{array}{l}\text { Rapid Growth Period } \\
\qquad(1989-2006)\end{array}$ & $\begin{array}{c}\text { Internationalization } \\
\text { Period } \\
(2007-2008) \\
\end{array}$ \\
\hline Formal & $\begin{array}{c}\text { - TLA } \\
\text { - Capital goods imports } \\
\text { - Technical } \\
\text { consultancies } \\
\text { - Turnkey project }\end{array}$ & $\begin{array}{c}\text { - FDI (backward-vertical } \\
\text { flows) } \\
\text { - TLA } \\
\text { - Capital goods imports } \\
\text { - Technical consultancies }\end{array}$ & $\begin{array}{l}\text { - FDI (horizontal } \\
\text { flows)* }\end{array}$ \\
\hline Informal & & $\begin{array}{l}\text { - Reverse engineering* } \\
\text { - International trade }\end{array}$ & \\
\hline
\end{tabular}

*Minor spillovers.

Table 3. Impacts of technology spillovers on the TC development of TRST, 1979-2008

\begin{tabular}{|c|c|c|c|c|}
\hline \multirow{2}{*}{ Mechanisms } & \multicolumn{4}{|c|}{ Level of Technological Capabilities } \\
\hline & Production & Investment & Adaptive & Innovative \\
\hline TLA & $S(S)$ & $S(S)$ & $S(S)$ & NS (NS) \\
\hline Capital goods import & $S(S)$ & $\mathrm{S}(\mathrm{NS})$ & $S(O S)$ & NS (NS) \\
\hline Technical consultancies & $S(S)$ & $S(N S)$ & OS (OS) & NS (NS) \\
\hline Turnkey project & $S(N / A)$ & $S(N / A)$ & $\mathrm{PS}(\mathrm{N} / \mathrm{A})$ & NS (N/A) \\
\hline FDI (horizontal) & N/A (S) & N/A (OS) & N/A (OS) & N/A (NS) \\
\hline FDI (vertical, backward) & $S(N / A)$ & $S(N / A)$ & OS (N/A) & NS (N/A) \\
\hline Reverse engineering & OS (N/A) & OS (N/A) & OS (N/A) & NS (N/A) \\
\hline Participation in overseas markets & $\mathrm{S}(\mathrm{PS})$ & $S(S)$ & PS (PS) & NS (NS) \\
\hline
\end{tabular}

Explanatory notes:

$S=$ Successful

PS = Potentially Successful

OS = Occasionally Successful NS = Not Successful

$\mathrm{N} / \mathrm{A}=$ Not Applicable

( ): comparison with the aggregated data of Thee (2005) 
With regard to TLA, it was apparent that since its start-up period the company has relied on this mechanism as the prime source of knowledge for production. Likewise, choosing turnkey projects as a mode of technology transfers during the start-up period was a great success. Moreover, imports of capital goods and technical assistances of suppliers from advanced economies played a significant role in the development of the company's TC. The impacts ranged from the operation and autonomous maintenances to the assessment and even the modification capabilities of the production processes along all of the periods. Nonetheless, the impacts of foreign education and training were low compared to technical assistance. This was because technical assistance was generally more practical in use.

Additional minor impacts from the turnkey projects became visible in the internationalization period, when the company took over a plant in China. It proved TRST successful in applying its production and investment capabilities into a ready-to-operate plant. More importantly, this particular TC may potentially be employed in the company's future international investments.

Since most of the technologies were acquired through direct transactional mode, then it was secure for the company to maximize its usage throughout the periods. However, this mechanism will not bring the company to have competitive advantage in product innovation. Therefore the future challenge is to endorse the contribution of the company's internal R\&D function in order to make radical product innovations to fight firece competitions locally and globally.

\section{The informal mode of transfers}

Some informal technology transfers in TRST has taken place through the mechanism of FDI, particularly through the vertical spillovers mechanism. However, the case of horizontal spillovers from FDI practically had no effect since there was no foreign investment operated in the Indonesian flexible packaging industry; except for a minor indication that was likely to take place in the internationalization period, when the company hired some local professionals with extensive previous experience in MNCs.

The influences of backward-vertical flows of spillovers were revealed in the cases where the company was appointed as the preferred supplier for MNCs which operated in the domestic personal care, tobacco and MSG industries, during the rapid growth period. The MNCs assisted the company in improving its managerial functions in terms of the adoption of ISO and better logistic management systems.

In the case of TRST, the evidence of reverse engineering as a mechanism of spillovers was not conspicuous, shown merely by the ability of the 
engineering team to conduct minor modifications into the imported production machineries. In many other cases, they still depended on technical helps and assistance from foreign suppliers. Product modifications were also quite small to consider.

Participation in overseas markets had been one of the important sources of technology spillovers, as revealed in the cases of insourcing activities to the Japanese and U.S. buyers. Opening the international representative office as well as the participation in international exhibitions offered many advantages of better communication with international buyers, understanding the global market trends and at the same time learning from the advancement of other producers. Accordingly, TC developments through this mechanism were modest. It is indicated by the abilities of the company to broaden its investments through the opening of several international representative offices and the participation in many international exhibitions.

\section{Assesment toward the knowledge management systems}

Considering that TRST was highly dependent on foreign technological innovations, the company implemented some initiatives to improve its TC, namely through building some mechanisms of knowledge management. The previous sections have pointed out some major mechanisms of knowledge management in the company.

First, since its fast growing period, the company has introduced intensive human resources traning and development programs. This was intended to cover knowledge diffusions of both technical and managerial functions at all organizational level and across units. Second, the company has established some units which functioned as the knowledge centers. This includes several independent units of R\&D Department, Projects Department, and Engineering Department. The R\&D Department was reponsible for developing TC in new product development. The Projects Department was particularly in charge of developing TC in assessing and setting up new investments of plant facility. The Engineering Department functioned to facilitate the dissemination of tacit knowledge in the production processes, the regeneration of engineers and technician, and to give assistance on non-routine improvement activities in the production units. Third, the company had instituted a unique medium of knowledge sharing through the daily online meeting in the production units. All of these had shown the high concern of the company toward the importance of coordination of learning and knowledge integration.

Furthermore, facing the increased challenges in the industry, TRST eventually expected to acquire TC in product innovations, which is the key competitive advantage in the industry. For instance, the establishment of R\&D Department in the rapid growth period was intended to discover new product 
innovations, that is in support to the company's product diversification strategy and to serve the growing demand of specialized products. Nevertheless, while TRST was able to learn from advanced foreign technology to operate, invest, and to a certain extent make minor changes, the company has not yet shown its capabilities in making product innovations. A clear evidence on this was the fiasco of the R\&D Department in producing new innovative products. This may indicate some limitations in the company's knowledge management systems especially in the processes of making the strategic use of the acquired foreign technologies. In particular, the R\&D function in the company has not yet been able to upgrade its TC from acquiring the know-how to the know-why of product innovations.

Overall, TRST has been successful on accumulating a minimum essential knowledge base during the three periods of development, especially on the technological and managerial functions of the production systems. Knowledge integration at this stage allowed the company to reduce costs, raise product quality, and improve its production technology to achieve parity with other advanced manufacturers in this industry. From this point of view, the company has done well in upgrading its indigenous TC to the intermediate-innovative level. However, this achievement was not enough to maintain the competitiveness of the company. TRST needed to continue doing its best efforts to upgrade the company's TC to the advanced-innovative level. At that moment, the company was still at its early transition stage to build its embryo of long-term and strategic capabilities.

\section{Conclusion}

In support to the previous studies, for instance by Thee $(2005,2001)$ and Blalock and Gertler (2005), the result of this study found some evidence on the influences of foreign technology transfers on the domestic company of a developing economy. In this case, along its development periods TRST benefited from international technology transfers especially through the major mechanisms of TLA, capital goods imports, turnkey projects, technical consultancies, backward-vertical flows of FDI, and participation in overseas markets (see Table 2).

This study also found that the impact of technology transfers toward the domestic company's indigenous TC is at intermediate level, indicated mostly by the production and investment capabilities and few indications of adaptive capability (see Table 3 ). This is generally in accordance with the aggregated 'national data' compiled in Thee (2005), except that the results on Table 3 seem to give a more promising figure. There was also an indication of the role of technology transfers toward the company's TC to assess and deliver its 
international production. This is following the typical development of MNCs from developing economies (Tolentino, 1993).

With regard to the findings, there are some managerial implications that can be suggested. First, in order to absorb more benefits from foreign technologies, a domestic company in developing economies needs to make more effort and investment on in-house R\&D activities as well on the human resource and organizational developments. All of these could work as catalysts of higher TC developments, especially for a company which produces technology-intensive products.

Second, a domestic company in developing economies needs to make improvements in its knowledge management systems, particularly with the intention of serving its innovative capabilities. In this sense, the domestic company needs to pay more attention to the aspects of coordination of learning and knowledge integration at all organizational levels. This would include some integrative mechanisms of: building small cross-functionals teamwork with broad tasks, settling overlapped problems among different stages of projects and production functions, creating a pool of knowledge and expertise, setting boundary spanning integrators (i.e. individuals who stand at the interface between different specialized units or internal and external knowledge bases), making strategic rotation of personel, and inducing informal communication networks in the organization (Dutrenit, 2000).

\section{References}

Blalock, G. and Gertler, P. J. (2005). Foreign Direct Investment and Externalities: The Case for Public Intervention. In: T. H. Moran, E. M. Graham and M. Blomstrom (Eds). Does Foreign Direct Investment Promote Development? Washington, DC: Institute for International Economics and Center for Global Development.

Chee, P. L. (1981, August). EEC Investment in ASEAN and the Transfer of Technology: A Malaysian Case Study. Paper presented at the First Conference on ASEAN-EEC Economic Relations, Singapore.

Cohen, W. M. and Levinthal, D. A. (1990). Absorptive Capacity: A New Perspective on Learning and Innovation. Administrative Science Quarterly, 35 (1).

Dunning, J. (1993). The Globalization of Business. London: Routledge.

Dutrenit, G. (2000). Learning and Knowledge Management in the Firm: From Knowledge Accumulation to Strategic Capabilities. Massachussetts: Edward Elgar Publishing.

Grossman, G. M. and Helpman, E. (1992). Innovation and Growth in the Global Economy. London: MIT Press. 
Jacob, J. and Szirmai, A. (2007). International Knowledge Spillovers to Developing Economies: The Case of Indonesia. Review of Developing Economics, 11 (3).

Kim, L. (1997). Imitation to Innovation: The Dynamics of Korea's Technological Learning. Boston: Harvard Business School Press.

Lipsey, R. E. and Sjoholm, F. (2005). The Impact of Inward FDI on Host Economies: Why Such Different Answers? In: T. H. Moran, E. M. Graham and M. Blomstrom (Eds). Does Foreign Direct Investment Promote Development? Washington, DC: Institute for International Economics and Center for Global Development.

Markusen, J. R. (1989). Trade in Producer Services and in Other Specialized Intermediate Inputs. American Economic Review, 79.

Pack, H. and Saggi, K. (2001). Vertical Technology Transfer via International Outsourcing. Journal of Development Economics, 65.

Pavitt, K. (1991). Key Characteristics of the Large Innovating Firms. British Journal of Management, 2, 41-50.

PT. Trias Sentosa, Tbk. Annual Report of 2005-2008. Retrieved from http://www.trias-sentosa.co.id, accessed at 14 May 2010.

Thee, K. W. (2001). Channels of International Technology Transfer in Indonesia: A Brief Survey. Working Paper Series of the International Center for the Study of East Asian Development, 2001 (32).

Thee, K. W. (2005). The Major Channels of International Technology Transfer to Indonesia: An Assessment. Journal of the Asia Pacific Economy, 10 (2).

Tolentino, P. E. E. (1993). Technological Innovation and Third World Multinationals. London: Routledge.

Unesco. (2010). Measuring R\&D: Challenge Faced by Developing Countries. Montreal: Unesco Institute for Statistics .

Xu, B. and Chiang, E. P. (2005). Trade, Patents and International Technology Diffusion. Journal of International Trade \& Economic Development, 14 (1), 115-135. 


\section{Abstrakt (in Polish)}

Międzynarodowe transfery technologii sq niezbędne dla gospodarek krajów rozwijajqcych się, ponieważ mogq one działać jako kluczowe czynniki napędzajqce rozwój gospodarczy. Dotychczasowe prace potwierdzaty istnienie pewnych kanałów transferu technologii w krajach rozwijajqcych się, niemniej jednak, dokładne mechanizmy opisujqce transfer technologii oraz jego skutki dla gospodarki kraju przyjmujqcego pozostajq niezbadane. Ponadto, zrozumienie przez krajowe firmy zarzqdzania wiedzq jest ważne, ponieważ określa zdolność firmy do absorpcji zaawansowanych technologii z zagranicy. Niniejsza praca wykorzystuje studium przypadku technologicznie średnio-zaawansowanego indonezyjskiego producenta, aby pokazać dowody międzynarodowych transferów technologicznych oraz ich wpływu na rozwój miejscowych zdolności technologicznych krajowej firmy, jak również w celu zbadania zarzqdzania wiedza $w$ firmie.

Niniejsza praca potwierdza korzyści płynq̨ce z międzynarodowych transferów wiedzy do firmy krajowej, w szczególności poprzez mechanizmy pomocy przy licencjach technicznych, importu dóbr kapitałowych, projektów realizowanych pod klucz, konsultacji technicznych, wstecznego-pionowego przepływu bezpośrednich inwestycji zagranicznych oraz obecności na rynkach zagranicznych. Jednakze powyższe wpływy na zdolności technologiczne krajowej firmy ogólnie pozostawały na średnim poziomie. Sugeruje to, iz firma ta powinna dokonać większych inwestycji we własna działaność $B+R$ oraz poprawić swój system zarzqdzania wiedzq.

Słowa kluczowe: transfery technologii, zdolności technologiczne, badanie i rozwój, zarzqdzanie wiedzq, gospodarki krajów rozwijajqcych się. 